\title{
Prospecting for sludge bacteria from a poultry slaughterhouse, with potential for degrading organic substances
}

\section{Prospecção de bactérias de lodo de abatedouro de aves com potencial degradador de substâncias orgânicas}

\author{
Jorge Avelino Rodriguez Lozada ${ }^{1}$; Klever Cristiano Silveira ${ }^{1}$; \\ Libério Junio da Silva ${ }^{1}$; Marihus Altoé Baldotto ${ }^{2}$; Lílian Estrela Borges Baldotto ${ }^{2 *}$
}

\begin{abstract}
The sludge produced in wastewater treatment plants of slaughterhouses is a rich source of chemical, organic, and microbiological constituents that can be biotechnologically exploited. The purpose of this study was to (i) conduct a chemical analysis of the sludge, and (ii) isolate, quantify, and describe the amylolytic, cellulolytic, ligninolytic, proteolytic, and keratinolytic bacteria in the sludge. Sludge samples were collected at the wastewater treatment plant of the Francap SA poultry company. The nutrient contents, $\mathrm{C} / \mathrm{N}$ ratio, and $\mathrm{pH}$ were determined. For the bacterial count, $10 \mathrm{~g}$ sludge was diluted in $90 \mathrm{~mL}$ saline solution, which was serially diluted to $10^{-12}$. Aliquots of $100 \mu \mathrm{L}$ of each dilution were transferred to selective media for isolation of bacteria that degrade organic substances. The colony-forming units were determined for each culture medium. Individual colonies were purified and characterized morphologically. The sludge contained $9.5,1.21$, and $0.45 \mathrm{dag} \mathrm{kg}^{-1}$ of $\mathrm{N}, \mathrm{P}$, and $\mathrm{K}$, respectively. Fiftytwo isolates were purified and characterized, with $2.11 \times 10^{12}$ to $9.55 \times 10^{15}$ colony-forming units per $\mathrm{g}$ sludge. In conclusion, the sludge generated in poultry slaughterhouse wastewater treatment plants is a rich source of organo-mineral constituents and bacteria with biotechnological potential for degrading organic substances.
\end{abstract}

Key words: Agricultural microbiology. Organic matter. Solid waste.

\section{Resumo}

Os lodos produzidos nas estações de tratamento de efluentes de abatedouros são uma fonte de riqueza química, orgânica e microbiológica que precisa ser explorada biotecnologicamente. Objetivou-se neste estudo: (i) realizar a caracterização química do lodo e (ii) isolar, quantificar e caracterizar bactérias amilolíticas, celulolíticas, ligninolíticas, proteolíticas e queratinolíticas do lodo. Amostras de lodo foram coletadas na estação de tratamento de efluentes da empresa avícola FRANCAP S.A. Foram determinados os teores de nutrientes, a relação $\mathrm{C} / \mathrm{N}$ e o $\mathrm{pH}$. Para a quantificação bacteriana, $10 \mathrm{~g}$ de lodo foram diluídos em $90 \mathrm{~mL}$ de solução salina e dela, realizaram-se diluições seriadas até $10^{-12}$. Alíquotas de 100 $\mu \mathrm{L}$ de cada diluição foram transferidas aos meios seletivos para isolamento de bactérias degradadoras de substâncias orgânicas. Determinaram-se as unidades formadoras de colônia para cada meio de cultivo. Colônias individuais foram purificadas e caracterizadas morfologicamente. O lodo apresentou teores de $\mathrm{N}, \mathrm{P}$ e K, de 9,5, 1,21 e $0,45 \mathrm{dag} \mathrm{kg}^{-1}$, respectivamente. Foram purificados e caracterizados 52 isolados, as unidades formadoras de colônia variaram entre 2,11 × $10^{12}$ a 9,55 × $10^{15}$. Conclui-se que os lodos gerados nas estações de tratamento de efluentes de abatedouro de aves são uma fonte de riqueza organomineral, além de apresentar bactérias com potencial biotecnológico de degradar substâncias orgânicas. Palavras-chave: Matéria orgânica. Microbiologia agrícola. Resíduos sólidos.

\footnotetext{
${ }^{1}$ Discentes. Programa de Pós-Graduação em Manejo e Conservação de Ecossitemas Naturais e Agrários, Universidade Federal de Viçosa, UFV, Campus Florestal, MG, Brasil. E-mail: jarodriguezlo28@gmail.com; klevercris@gmail.com; liberiojunior@gmail.com ${ }^{2}$ Prof $^{\text {as }}$, Universidade Federal de Viçosa, UFV, Campus Florestal, MG, Brasil. E-mail: marihus@ufv.br; liestrelaborges@gmail.com ${ }^{*}$ Author for correspondence
} 


\section{Introduction}

In 2013, Brazil produced 12.3 million tons of poultry, of which $69 \%$ was used locally and $31 \%$ was used in the international market (UBABEF, 2014). The state of Minas Gerais accounts for $8 \%$ of the total output and ranks fourth in poultry production. Despite the existence of many poultry farms, only 300 are registered in the State (IMA, 2013), hampering the control of the processes and management of by-products of this agricultural industry.

One of the by-products generated in the poultry industry is sludge from treatment of slaughterhouse effluent, defined as a mixture of substances consisting of mineral colloids, particles, and decomposed organic matter in aqueous medium (CONAMA, 2006).

If untreated, the disposal of such sludge leads to water and soil contamination, odor, and increased incidence of diseases (HECK et al., 2012). To avoid these problems, the material is transferred to landfills, incinerated, recycled, composted, or transformed into biofertilizers (HECK et al., 2012). For application in agriculture, the sludge should be analyzed for agronomic potential, and for toxic substances and pathogens. The presence of viable helminth eggs, salmonella, and enteric viruses should also be assessed (CONAMA, 2006), with special consideration to heat-tolerant coliforms.

Apart from pathogenic microorganisms, sludge can potentially harbor non-pathogenic microorganisms, such as bacteria that degrade organic substances. Among these are: (i) amylolytic bacteria that convert starch into fatty acids (GABARRA, 2001), (ii) cellulolytic bacteria that degrade polymeric carbohydrates (PIRES, 2008), (iii) ligninolytic bacteria that use lignin as a carbon source (BASTOS-NETO, 2012), (iv) proteolytic bacteria that degrade proteins (CARPINÉ et al., 2010), and (v) keratinolytic bacteria that decompose keratinized structures (PACHECO, 2013).

In this context, biotechnology research is needed to focus on the selection of bacteria able to transform and reduce organic by-products, hence mitigating environmental impacts.

The purpose of this study was to (i) chemically characterize the sludge generated in the wastewater treatment plant of a poultry slaughterhouse, and (ii) isolate, quantify, and characterize bacteria, with potential for degrading organic matter, from the sludge.

\section{Material and Methods}

\section{Collecting sludge samples}

Sludge samples were collected from the wastewater treatment system of the Activated Sludge/Extended Aeration type at a poultry slaughterhouse of FRANCAP S.A., in the city of Pará de Minas, MG (FRANCAP, 2015). Samples were transported to the floriculture sector of the Universidade Federal de Viçosa - Campus Florestal, where microbiological analyses were carried out in 2013 and 2014.

\section{Chemical analysis of the sludge}

Sludge samples were dried in a forced circulation oven at $60{ }^{\circ} \mathrm{C}$ and sent to the Soil Analysis Laboratory Viçosa Ltd. to determine the total contents of nitrogen $(\mathrm{N})$, phosphorus $(\mathrm{P})$, potassium $(\mathrm{K})$, calcium $(\mathrm{Ca})$, magnesium $(\mathrm{Mg})$, sulfur $(\mathrm{S})$, iron $(\mathrm{Fe})$, zinc $(\mathrm{Zn})$, copper $(\mathrm{Cu})$, manganese $(\mathrm{Mn})$, boron (B), and cobalt (Co), as well as the percentage of organic carbon $(\mathrm{C}), \mathrm{C} / \mathrm{N}$ ratio, and $\mathrm{pH}$ (EMBRAPA, 1997).

Isolation and quantification of bacteria degrading organic matter

Sludge samples $(10 \mathrm{~g})$ were resuspended in 90 $\mathrm{mL}$ saline solution $\left(\mathrm{NaCl}, 0.85 \mathrm{~g} \mathrm{~L}^{-1}\right)$, and diluted serially in 10 -fold steps to $10^{-12}$.

For the isolation of amylolytic bacteria, $100-\mu \mathrm{L}$ aliquots of each dilution were transferred to Petri dishes containing solid medium, containing the 
following (per liter of distilled water): $10 \mathrm{~g}$ starch, $0.4 \mathrm{~g}$ ammonium chloride $\left(\mathrm{NH}_{4} \mathrm{Cl}\right), 0.8 \mathrm{~g}$ dibasic potassium phosphate $\left(\mathrm{K}_{2} \mathrm{HPO}_{4}\right), 0.12 \mathrm{~g}$ calcium chloride $\left(\mathrm{CaCl}_{2} \cdot 2 \mathrm{H}_{2} \mathrm{O}\right), 0.12 \mathrm{~g}$ magnesium sulfate $\left(\mathrm{MgSO}_{4} .7 \mathrm{H}_{2} \mathrm{O}\right) 15 \mathrm{~g}$ bacteriological agar, and 2 $\mathrm{mL}$ of the fungicide Cerconil $\left(0.1 \mathrm{~g} \mathrm{~L}^{-1}\right)$. The $\mathrm{pH}$ was adjusted to 6.5 with sulfuric acid $\left(\mathrm{H}_{2} \mathrm{SO}_{4}\right)$ and/or potassium hydroxide $(\mathrm{KOH})$. The plates were incubated at $30{ }^{\circ} \mathrm{C}$ for 3 days. After growth of the colonies, staining was performed with lugol (potassium iodide, KI, 4\%); the formation of a translucent halo around the colony indicated amylase activity (BASTOS-NETO et al., 2012).

For the isolation of cellulolytic bacteria, samples of $100 \mu \mathrm{L}$ of each dilution were transferred to Petri dishes with solid medium, containing the following (per liter of distilled water): $10 \mathrm{~g}$ microcrystalline cellulose (MCC), $3 \mathrm{~g}$ sodium nitrate $\left(\mathrm{NaNO}_{3}\right), 1$ $\mathrm{g}$ ammonium sulfate $\left[\left(\mathrm{NH}_{4}\right)_{2} \mathrm{SO}_{4}\right], 0.5 \mathrm{~g} \mathrm{MgSO}_{4}$, $0.5 \mathrm{~g}$ potassium chloride $(\mathrm{KCl}), 10 \mathrm{~g}$ iron sulfate heptahydrate $\left(\mathrm{FeSO}_{4} \cdot 7 \mathrm{H}_{2} \mathrm{O}\right), 20 \mathrm{~g}$ bacteriological agar, and $2 \mathrm{~mL}$ Cerconil $\left(0.1 \mathrm{~g} \mathrm{~L}^{-1}\right)$, with the $\mathrm{pH}$ adjusted to 6.5 with $\mathrm{H}_{2} \mathrm{SO}_{4}$ and/or $\mathrm{KOH}$. After incubation at $30^{\circ} \mathrm{C}$ for 3 days, $10 \mathrm{~mL}$ Congo red dye (2.5 $\left.\mathrm{g} \mathrm{L}^{-1}\right)$ in $0.1 \mathrm{~mol} \mathrm{~L}^{-1}$ Tris-HCl buffer, $\mathrm{pH} 8.0$, was added to the plates for $30 \mathrm{~min}$, followed by washing with $5 \mathrm{~mL} \mathrm{NaCl}\left(0.5 \mathrm{mmol} \mathrm{L}^{-1}\right)$ (BORTOLAZZO, 2011).

For the isolation of ligninolytic bacteria, $100 \mu \mathrm{L}$ samples per dilution were transferred to Petri dishes with solid medium, containing the following (per liter of distilled water): $1.2 \mathrm{~g} \mathrm{NaNO}_{3}, 3.0 \mathrm{~g}$ monobasic potassium phosphate $\left(\mathrm{KH}_{2} \mathrm{PO}_{4}\right), 6.0 \mathrm{~g} \mathrm{~K}_{2} \mathrm{HPO}_{4}, 0.2$ g $\mathrm{MgSO}_{4} .7 \mathrm{H}_{2} \mathrm{O}, 0.05 \mathrm{~g} \mathrm{CaCl}_{2} .2 \mathrm{H}_{2} \mathrm{O}, 0.001 \mathrm{~g}$ zinc sulfate $\left(\mathrm{ZnSO}_{4} .7 \mathrm{H}_{2} \mathrm{O}\right), 0.01 \mathrm{~g}$ manganese sulfate $\left(\mathrm{MnSO}_{4} \cdot 7 \mathrm{H}_{2} \mathrm{O}\right), 1.0 \mathrm{~g}$ yeast extract, $10.0 \mathrm{~g}$ lignin, $15 \mathrm{~g}$ bacteriological agar, and $2 \mathrm{~mL}$ Cerconil $(0.1 \mathrm{~g}$ $\mathrm{L}^{-1}$ ), with the $\mathrm{pH}$ adjusted to 6.5 with $\mathrm{H}_{2} \mathrm{SO}_{4}$ and/or $\mathrm{KOH}$. The dishes were incubated at $30^{\circ} \mathrm{C}$ for 3 days (MARTINEZ, 2009).

For the isolation of proteolytic bacteria, $100 \mu \mathrm{L}$ samples per dilution were transferred to Petri dishes with solid medium, containing the following (per liter of distilled water): $100 \mathrm{~mL}$ skimmed milk, $5 \mathrm{~g}$ meat peptone, $3 \mathrm{~g}$ yeast extract, $12 \mathrm{~g}$ bacteriological agar, and $4 \mathrm{~mL}$ Cerconil $\left(0.1 \mathrm{~g} \mathrm{~L}^{-1}\right)$, with the $\mathrm{pH}$ adjusted to 6.5 with $\mathrm{H}_{2} \mathrm{SO}_{4}$ and/or $\mathrm{KOH}$. The dishes were incubated at $30^{\circ} \mathrm{C}$ for 3 days (BACH, 2010).

To isolate keratinolytic bacteria, $100 \mu \mathrm{L}$ samples per dilution were placed on Petri dishes with solid medium, containing the following (per liter of distilled water): $1 \mathrm{~g}$ feather meal, $0.5 \mathrm{~g} \mathrm{NaCl}, 0.3 \mathrm{~g}$ $\mathrm{K}_{2} \mathrm{HPO}_{4}, 0.4 \mathrm{~g} \mathrm{KH}_{2} \mathrm{PO}_{4}, 15 \mathrm{~g}$ bacteriological agar, and $2 \mathrm{~mL}$ Cerconil $\left(0.1 \mathrm{~g} \mathrm{~L}^{-1}\right)$, with the $\mathrm{pH}$ adjusted to 6.5 with $\mathrm{H}_{2} \mathrm{SO}_{4}$ and/or $\mathrm{KOH}$. The feather meal was prepared by soaking the feathers in $1 \%$ Triton $\mathrm{X}-100$ detergent for $24 \mathrm{~h}$, followed by washing in distilled water, drying at $60{ }^{\circ} \mathrm{C}$, and grinding in a Wiley mill $(\mathrm{BACH}, 2010)$. The plates were incubated at $30{ }^{\circ} \mathrm{C}$ for 3 days.

For all culture media, the bacteria were quantified by counting the colony-forming units ( $\mathrm{CFU})$.

For purification of bacterial isolates, the individual colonies from the highest dilutions were transferred from the culture media to liquid DYGS medium (2 g glucose, $2 \mathrm{~g}$ malic acid, 1.5 $\mathrm{g}$ bacteriological peptone, $2 \mathrm{~g}$ yeast extract, $0.5 \mathrm{~g}$ $\mathrm{K}_{2} \mathrm{HPO}_{4}, 0.5 \mathrm{~g} \mathrm{MgSO}_{4} .7 \mathrm{H}_{2} \mathrm{O}$, and $1.5 \mathrm{~g}$ glutamic acid in $1000 \mathrm{~mL}$ distilled water, adjusted to $\mathrm{pH}$ 6.8) and maintained at $30{ }^{\circ} \mathrm{C}$ and $120 \mathrm{rpm}$ for 24 h. The bacteria were then transferred to Petri dishes containing the same growth medium to check the purity of the isolates. Isolates were stored in plastic microtubes containing autoclaved distilled water for routine use.

\section{Morphological characterization of bacterial isolates}

All bacterial isolates were analyzed based on the characteristics of colonies and cells. After 5 days of growth on solid DYGS medium, bacterial colonies were characterized for their size, shape (round or irregular), top (flat, lens, convex, pulvinate, umbonate, umbilicated), edge (undulated, lobed, indented, filamentous, integer), and surface (flat, rough, papillate), as proposed by Perin (2002). The cells were described based on the variable cell shape 
and Gram staining. The Gram test involved treating a bacterial smear on a slide successively with crystal violet reagent for $1 \mathrm{~min}$, lugol for $1 \mathrm{~min}$, alcohol for $5 \mathrm{~s}$, and safranin for $30 \mathrm{~s}$. Thereafter, the slide was examined under an optical microscope. Bacteria that stained blue-violet were characterized as grampositive and those that stained red as gram-negative.

\section{Statistical analysis}

The CFU data were log-transformed for subsequentcalculation of the mean and mean standard error for each medium, with three replications.

\section{Results and Discussion}

\section{Chemical sludge analysis}

The values in Table 1 and several previous studies (COSTA et al., 2008; SOUSA NETO et al., 2012; RIBEIRO et al., 2012; SANTOS et al.,
2014) showed that the sludge is a rich chemical and organic source and can be exploited for different uses. According to Resolution No. 375 of CONAMA of August 29, 2006, the sludge can be used as biofertilizer for crops that are not pasture or vegetable species, tubers, and flooded crops or for other crops whose edible portion is in contact with the soil. It can also be used in substrates, as soil conditioners and, as demonstrated in this study, as an initial source for the isolation of bacteria with biotechnological potential.

\section{Quantification and isolation of bacteria degrading organic substances}

Table 2 shows the numbers of aerobic bacterial isolates with the potential to degrade different organic compounds through selective culture, the respective dilution, and quantification of CFU.

Table 1. Chemical analysis of sludge from the activated sludge/extended aeration treatment station of the company FRANCAP S.A.

\begin{tabular}{|c|c|c|c|c|c|c|c|c|c|c|c|c|c|}
\hline $\mathbf{N}$ & $\mathbf{P}$ & $\mathbf{K}$ & $\mathrm{Ca}$ & Mg & $\mathbf{S}$ & $\mathrm{C}$ & $\mathrm{Zn}$ & $\mathbf{F e}$ & Mn & $\mathbf{C u}$ & B & pH & $\mathrm{C} / \mathrm{N}$ \\
\hline & & 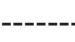 & -dag & & 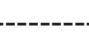 & ---- & & ------י & /kg-- & 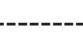 & & $\left(\mathrm{H}_{2} 0\right)$ & \\
\hline 9.5 & 1.21 & 0.45 & 1.35 & 0.18 & 0.77 & 18.72 & 517 & 1908 & 114 & 342 & 8.3 & 6.7 & 1.96 \\
\hline
\end{tabular}

Total contents, determined in acid extract (nitric acid with perchloric acid)

$\mathrm{N}$ - Kjeldahl method

C - Walkley-Black method.

Table 2. Number of bacterial isolates through selective culturing, the respective dilution, and quantification of colonyforming units (CFU).

\begin{tabular}{lccc}
\hline \multicolumn{1}{c}{ Culture medium } & Number of isolates & Dilution & $\begin{array}{c}\text { CFU } \\
\text { (log CFU/g sludge) }\end{array}$ \\
\hline Amylolytic & 10 & $10^{-9}$ & 12.8 \\
Cellulolytic & 2 & $10^{-12}$ & 16.0 \\
Keratinolytic & 15 & $10^{-8}$ & 13.5 \\
Ligninolytic & 10 & $10^{-10}$ & 14.0 \\
Proteolytic & 15 & $10^{-8}$ & 12.0 \\
\hline
\end{tabular}


These results reflect the type of wastewater management used by the company FRANCAP S.A., which is activated sludge with extended aeration. The activated sludge system used in the wastewater treatment is a process in which a biological mass grows and flocculates as long as oxygen is present, thus permitting the proliferation of aerobic microorganisms (SOBRINHO, 1983). In this regard, 52 morphotypes of aerobic bacteria were isolated from the five selective media for organic matter-degrading microbes, since 95\% of the microbial population present in the organic matter belongs to the group of decomposing and, mainly, heterotrophic bacteria, responsible for the biodegradation of the soluble organic fraction of the matrix (FERREIRA et al., 2006).

The number of amylolytic bacterial isolates, (10; Table 2) corresponds proportionally to the results of Bastos-Neto et al. (2012), who found 19 morphotypes of bacteria isolated from cassava peel. The result of the logarithmic conversion of CFU reported by these authors was lower (7.4) than the value found in this study (12.8). This fact confirms the microbiological abundance of amylases contained in the sludge, with the potential for biotechnological production of amylase enzymes (ALBUQUERQUE et al., 2010).

For the cellulolytic strains, the results in Table 1 show only two bacterial isolates, but the absolute CFU values were higher (16 log CFU/g sludge). It is worth mentioning that the morphological differentiation of the bacteria was hampered by the dark color of this culture medium and the fact that most bacterial colonies were translucent. There are reports on the isolation of 39 morphotypes of bacteria, of which nine tested positive for degradation of forest litter cellulose (MANTILLA; PINEDA, 2013).
For keratinolytic bacteria, there were 15 isolates and $13.5 \log \mathrm{CFU} / \mathrm{g}$ sludge (Table 2). These values of the poultry slaughterhouse sludge are considered high for this category. Lucas et al. (2003) found 33 keratinolytic bacterial isolates directly from chicken feathers.

The number of isolates and CFU values were highest for ligninolytic bacteria (Table 2). Few studies have addressed the isolation of lignindecomposing bacteria. Investigating the biodiversity of bacteria in lignocellulolytic litter of the Atlantic Forest, Martinez (2009) reported 51 morphotypes of bacteria and $8 \log \mathrm{CFU} / \mathrm{g}$ compost; the same author stated that of the total bacteria, only $20 \%$ had the ability to degrade lignin.

Of the bacteria studied, the proteolytic ones had the lowest CFU values (Figure 1), despite the high ability to colonize and persist in different types of environments. Values of $6.5 \log \mathrm{CFU} / \mathrm{mL}$ were reported in raw milk cooled to $2{ }^{\circ} \mathrm{C}$, indicating a high concentration of this type of bacteria (ARCURI et al., 2008). Along this line of research, $2.3 \log$ CFU/ $\mathrm{mL}$ were reported in another study on milk cooled to $4{ }^{\circ} \mathrm{C}$ (PINTO et al., 2006), reaffirming the ability of proteolytic bacteria to persist under different environmental conditions.

\section{Morphological characterization of bacterial isolates}

The 52 bacterial isolates obtained from poultry slaughterhouse sludge were analyzed based on their cell shape and Gram staining, and on the criteria proposed by Perin (2002). The results (Tables 3 and 4 , respectively) show high morphological diversity of the bacterial colonies isolated from the sludge from the wastewater treatment plant of the poultry slaughterhouse. 
Table 3. Cell characterization of bacteria isolated from sludge from a wastewater treatment plant of a poultry slaughterhouse.

\begin{tabular}{lll}
\hline Isolates & Cell shape & Gram stain \\
\hline Amylolytic & $50 \%$ rod & $100 \%$ positive \\
& $50 \%$ coccoid & \\
Cellulolytic & un. & un. \\
Ligninolytic & $10 \%$ rod & $90 \%$ positive \\
& $90 \%$ coccoid & $10 \%$ negative \\
Proteolytic & $30 \%$ rod & $90 \%$ positive \\
& $70 \%$ coccoid & $10 \%$ negative \\
Keratinolytic & $30 \%$ rod & $90 \%$ positive \\
& $70 \%$ coccoid & $10 \%$ negative \\
\hline
\end{tabular}

un. : unidentified.

Table 4. Morphological characterization of the colonies of 52 bacterial isolates from the sludge of the wastewater treatment station of a poultry slaughterhouse.

\begin{tabular}{|c|c|c|c|c|c|c|c|}
\hline Isolates & Size & Shape & Top & Edge & Surface & Color & Mucoid \\
\hline Amylolytic & $\begin{array}{l}60 \% \geq 1 \mathrm{~mm} \\
40 \%<1 \mathrm{~mm}\end{array}$ & $\begin{array}{c}90 \% \text { round } \\
10 \% \text { irregular }\end{array}$ & $\begin{array}{l}80 \% \text { flat } \\
20 \% \text { lense }\end{array}$ & $\begin{array}{c}70 \% \text { straight } \\
20 \% \text { undulated } \\
10 \% \text { indented }\end{array}$ & $\begin{array}{l}90 \% \text { smooth } \\
10 \% \text { rough }\end{array}$ & $100 \%$ white & - \\
\hline Cellulolytic & un. & $100 \%$ round & un. & $100 \%$ straight & un. & $100 \%$ translucent & - \\
\hline Ligninolytic & $100 \% \geq 1 \mathrm{~mm}$ & $\begin{array}{l}71 \% \text { round } \\
29 \% \text { irregular }\end{array}$ & $\begin{array}{c}64 \% \text { flat } \\
26 \% \text { lense }\end{array}$ & $\begin{array}{c}64 \% \text { straight } \\
21 \% \text { indented } \\
15 \% \text { lobed }\end{array}$ & $100 \%$ smooth & $\begin{array}{c}79 \% \text { white } \\
21 \% \text { translucent }\end{array}$ & - \\
\hline Proteolytic & $\begin{array}{l}89 \% \geq 1 \mathrm{~mm} \\
11 \%<1 \mathrm{~mm}\end{array}$ & $\begin{array}{c}67 \% \text { round } \\
33 \% \text { irregular }\end{array}$ & $\begin{array}{c}56 \% \text { convex } \\
44 \% \text { lense }\end{array}$ & $\begin{array}{l}80 \% \text { straight } \\
20 \% \text { undulated }\end{array}$ & $\begin{array}{l}90 \% \text { smooth } \\
10 \% \text { rough }\end{array}$ & $\begin{array}{c}70 \% \text { white } \\
20 \% \text { cream } \\
10 \% \text { red }\end{array}$ & + \\
\hline Keratinolytic & $\begin{array}{l}67 \% \geq 1 \mathrm{~mm} \\
33 \%<1 \mathrm{~mm}\end{array}$ & $\begin{array}{c}80 \% \text { round } \\
20 \% \text { irregular }\end{array}$ & $\begin{array}{c}60 \% \text { flat } \\
26 \% \text { lense } \\
14 \% \text { convex }\end{array}$ & $\begin{array}{l}93 \% \text { straight } \\
7 \% \text { indented }\end{array}$ & $100 \%$ smooth & $\begin{array}{c}73 \% \text { white } \\
27 \% \text { translucent }\end{array}$ & - \\
\hline
\end{tabular}

un. : unidentified.

$-:$ absent;

+ : present.

Although the bacterial strains had a wide diversity of colony colors, shapes, and sizes, they generally followed a trend, for example, about $80 \%$ had a colony size greater than $1 \mathrm{~mm}$, a straight edge, coccoid cell shape, and were gram-positive. A high incidence of gram-positive bacteria was also reported by Faria et al. (2006), in the sludge of sewage treatment plants of Franca and Barueri (77\% and $61 \%$ of a total of 77 and 143 isolates, respectively). These authors concluded that the most common gram-positive bacteria in the sludge belonged to the genus Bacillus.
This study showed that sludge from wastewater treatment plants of poultry slaughterhouses contains microorganisms that interact and coexist, with specific functions and/or with the potential to degrade various organic compounds or substances. This high diversity allows investigations at several research fronts, with a view to identify biotechnological processes applicable in different fields. One potential area is minimizing the environmental impact of waste in urban and agricultural settings. The by-products from agricultural residues, sewage sludge, and household 
waste can be diverted to nutrient cycling processes by the action of microbial organic-matter degraders, thus reducing environmental impacts.

\section{Conclusions}

The sludge from wastewater treatment plants of poultry slaughterhouses is a rich source of organo-mineral constituents, and of functional and morphologically diverse bacteria with the potential to degrade organic matter.

The sludge contains, in order of increasing number of types of bacterial isolates: cellulolytic, ligninolytic, amylolytic, keratinolytic, and proteolytic bacteria.

\section{Acknowledgments}

The authors thank the company FRANCAP S.A. and Débora Durães, a laboratory technician at the Universidade Federal de Viçosa - Campus Florestal (UFV-CAF). They also thank Fundação Arthur Bernardes (FUNARBE) for financial support and the Brazilian Coordination for the Improvement of Higher Education Personnel (CAPES) for a graduate scholarship awarded to the first author J.A.R.L., in the area of Management and Conservation of Natural and Agrarian Ecosystems, UFV-CAF.

\section{References}

ALBUQUERQUE, U. S. de; SALES, A. E.; TAKAKI, G. M. C.; MESSIAS, A. S.; SILVA, C. A. da. Detecção de amilase e urease em bactérias mesofílicas isoladas de lodo de esgoto da estação de tratamento Mangueira, Recife - Pernambuco. Exacta, São Paulo, v. 8, n. 3, p. 289-298, 2010.

ARCURI, E. F.; SILVA, P. D. L. da.; BRITO, M. A. V. P.; BRITO, J. R. F.; LANGE, C. C.; MAGALHÃES, M. M. A. Contagem, isolamento e caracterização de bactérias psicrotróficas contaminantes de leite cru refrigerado. Ciência Rural, Santa Maria, v. 38, n. 8, p. 250-255, 2008.

$\mathrm{BACH}$, E. Seleção, caracterização e identificação de bactérias queratinolíticas provenientes de solos brasileiros. 2010. Dissertação (Mestrado em
Microbiologia Agrícola e do Ambiente) - Universidade Federal do Rio Grande do Sul, Porto Alegre.

BASTOS-NETO, B. S.; RECAREY, H. A.; ESPÍRITOSANTOS, A. A.; MOREAU, V. H.; FERRÃOGONZÁLES, A. D. Isolamento e caracterização de microrganismos amilolíticos presentes na rizosfera de tuberosas amilaceas. Diálogos \& Ciência, Salvador, v. 10, n. 30, p. 153-158, 2012.

BORTOLAZZO, N. G. Isolamento e seleção de fungos celulolíticos para hidrólise enzimática do bagaço de cana-de-açúcar. 2011. Dissertação (Mestrado em Ciências) - Universidade de São Paulo, Piracicaba.

CARPINÉ, D.; DAGOSTIN, J. L. A.; DALLA SANTA, H. S.; ALVAREZ, D. C.; TERRA, N. N.; DALLA SANTA, O. R. Atividade proteolítica e lipolítica de bactérias isoladas de salames artesanais. Ambiência, Guarapuava, v. 6, n. 1, p. 125-132, 2010.

CONSELHO NACIONAL DO MEIO AMBIENTE CONAMA. Resolução no 375 de 29 de agosto de 2006. Brasília: Ministério do Meio Ambiente, 2006. Disponível em: <http://www.mma.gov.br/port/conama/res/ res06/ res37506.pdf $>$. Acesso em: 20 ago. 2015.

COSTA, C. L. L.; COSTA, Z. V. B. da; COSTA JÚNIOR, C. D. O.; ANDRADE, R.; SANTOS, J. G. R. dos. Utilização de bioestimulante na produção de mudas de melancia. Revista Verde, Pmbal, v. 3, n. 3, p. 110-115, 2008.

EMPRESA BRASILEIRA DE PESQUISA AGROPECUÁRIA - EMBRAPA. Manual de métodos de análise do solo. 2. ed. Rio de Janeiro: EMPRAPA, 1997. $212 \mathrm{p}$.

FARIA, C. M. D. R.; CAMPOS, V. P.; SOUZA, R. M. de; MOREIRA, F. M. S.; MOURA, B. de; RIBEIRO, L. O.; FARIAS, M. V. Isolamento e caracterização de bactérias do lodo de esgoto com potencial antagonismo a nematóides. Ambiência, Guarapuava, v. 2, n. 2, p. $247-$ 256, 2006.

FERREIRA, S. J. F.; LUIZÃO, F. J.; MIRANDA, S. Á. F.; SILVA, M. S. R. da; VITAL, A. R. T. Nutrientes na solução do solo em floresta de terra firme na Amazônia central submetida à extração seletiva de madeira. Acta Amazônica, Manaus, v. 36, n. 1, p. 59-68, 2006.

FRANCAP. Pará de Minas. [S.1.: s.n.], 2015. Disponível em: $<$ http://www.francap.ind.br>. Acesso em: 20 ago. 2015.

GABARRA, P. Digestibilidade de nutrientes $e$ parâmetros ruminais e sanguíneos de novilhos Nerole alimentados com fontes proteicas e energéticas com diferentes degrabilidades ruminais. 2001. Dissertação (Mestrado em Ciências) - Universidade de São Paulo, Piracicaba. 
HECK, K.; MARCO, É. G. de; HAHN, A. B. B.; KLUGE, M.; SPILKI, F. R.; VAN DER SAND, S. T. Temperatura de degradação de resíduos em processo de compostagem e qualidade microbiológica do composto final. Revista Brasileira de Engenharia Agrícola e Ambiental, Campina Grande, v. 17, n. 1, p. 54-59, 2012.

INSTITUTO MINEIRO AGROPECUÁRIO - IMA. Belo Horizonte, 2013. Disponível em: <http:// www.ima.mg.gov.br/produtos-de-origem-animal2/ estabelecimentos-registrados $>$. Acesso em: 21 ago. 2015.

LUCAS, S. F.; BROENNIMANN, O.; FEBBRARO, I.; HEEB, P. High diversity among feather-degrading bacteria from a dry meadow soil. Microbial Ecology, New York, v. 45, n. 3, p. 282-290, 2003.

MANTILLA, C. L.; PINEDA, R. C. A. Bacterias celulolíticas aisladas del intestino de termitas (Nasutitermes nigriceps) con características probióticas y potencial en la degradación del pasto. Revista Colombiana de Biotecnología, Bogotá, v. 15, n. 1, p. 8-16, 2013.

MARTINEZ, I. B. Biodiversidade de bactérias lignocelulolíticas da Mata Atlântica do Estado do Rio de Janeiro. 2009. Dissertação (Mestrado em Microbiologia e Parasitologia Aplicadas) - Universidade Federal Fluminense, Niterói.

PACHECO, G. Avaliação de complexos enzimáticos sobre o farelo de arroz integral e farinha de penas em dietas de cães. 2013. Dissertação (Mestrado em Zootecnia) - Universidade Federal de Rio Grande do Sul, Porto Alegre.

PERIN, L. Ecologia e diversidade de Glucanocetobacter diazotrophicus associada à cana-de-açúcar (Saccharum spp.). 2002. Dissertação (Mestrado em Agronomia) - Universidade Federal Rural do Rio de Janeiro, Seropédica.
PINTO, C. L. O.; MARTINS, M. L.; VANETTI, M. C. D. Qualidade microbiológica de leite cru refrigerado e isolamento de bactérias psicrotróficas proteolíticas. Ciência Tecnológica do Alimento, Campinas, v. 26, n. 3, p. 645-651, 2006.

PIRES, V. Estrutura e função de módulos não catalíticos envolvidos na degradação da parede celular vegetal: o efeito de enzimas exógenas na valorização nutritiva de dietas à base de Lupinus albus para leitões. 2008. Tese (Doutorado em Ciências Veterinárias) - Universidade Técnica de Lisboa, Lisboa.

RIBEIRO, M. C. F.; ROCHA, F. A.; SANTOS, A. C. dos; SILVA, J. O. da; PEIXOTO, M. F. S. P.; PAZ, V. P. S. Crescimento e produtividade da mamoneira irrigada com diferentes diluições de esgoto doméstico tratado. Revista Brasileira de Engenharia Agrícola e Ambiental, Campina Grande, v. 16, n. 6, p. 639-646, 2012.

SANTOS, F. E. V.; KUNZ, S. H.; CALDEIRA, M. V. W.; AZEVEDO, C. H. S.; RANGEL, O. J. P. Características químicas de substratos formulados com lodo de esgoto para produção de mudas florestais. Revista Brasileira de Engenharia Agrícola e Ambiental, Campina Grande, v. 18, n. 9, p. 971-979, 2014.

SOBRINHO, P. A. Estudo dos fatores que influenciam no processo de lodos ativados - determinação de parâmetros de projeto para esgotos predominantemente domésticos. Revista DAE, São Paulo, v. 132, n. 1, p. 49-85, 1983.

SOUSA NETO, O. N.; ANDRADE FILHO, J.; DIAS, N. D. S.; REBOUÇAS, J. R. L.; OLIVEIRA, F. R. A. de; DINIZ, A. A. Fertigação do algodoeiro utilizando efluente doméstico tratado. Revista Brasileira de Engenharia Agrícola e Ambiental, Campina Grande, v. 16, n. 2, p. 200-208, 2012.

UNIÃO BRASILEIRA DE AVICULTURA - UBABEF. São Paulo: [s.n.], 2014. Disponível em: <http://www. ubabef.com.br/files/publicacoes/8ca705e70f0cb110ae3a ed67d29c8842.pdf>. Acesso em: 20 ago. 2015. 